PACS: $87.14 . \mathrm{C}++\mathrm{c}$, 87.16.Dg

\title{
NOVEL TRIMETHINE CYANINE DYE AS POTENTIAL AMYLOID MARKER
}

\author{
U. Tarabara ${ }^{1 *}$, (D) Ryzhova ${ }^{1}$, (D) K. Vus ${ }^{1}$, (D) A. Kurutos ${ }^{2}$, (D) V. Trusova ${ }^{1}$, (D) G. Gorbenko1, \\ N. Gadjev² T. Deligeorgiev ${ }^{2}$ \\ ${ }^{1}$ Department of Nuclear and Medical Physics, V.N. Karazin Kharkiv National University \\ 4 Svobody Sq., Kharkiv, 61022, Ukraine \\ ${ }^{2}$ Faculty of Chemistry and Pharmacy, Sofia University, "St. Kliment Ohridski” 1 \\ blv. J. Bourchier, Sofia, 1164, Bulgaria \\ *E-mail: uliana.tarabara@gmail.com \\ Received 11 November 2018, accepted 4 December 2018
}

The applicability of the novel cyanine dye AK 3-1 to the detection and characterization of pathogenic protein aggregates, amyloid fibrils, was tested using the absorption spectroscopy technique. In an organic solvent dimethyl sulfoxide (DMSO), absorption spectra of AK3-1 exhibits vibrational structure with the relative intensity of 0-0 sub-band being higher than that for the $0-1$ sub-band. In an aqueous phase the dye absorption band undergoes hypsochromic shift relative to DMSO due to H-aggregation of the dye. The interaction of AK3-1 with the native and fibrillar insulin was followed by the decrease of monomer band and the enhancement of $\mathrm{H}-$ dimer band. To evaluate the relative contributions of the monomeric and aggregated forms, the absorption spectra of the proteinbound dye were deconvoluted using the asymmetric log-normal (LN) function. The analysis of the set of fitting parameters provides evidence for the protein-induced AK3-1 self-association into the head-to-head dimers, with the magnitude of this effect being much more pronounced for fibrillar protein form. The molecular docking studies showed that the AK3-1 monomer tends to associate with the specific arrangement of side chains in the $\beta$-sheet formed by L17 leucine residues (of the insulin B-chain), located on the dry steric zipper interface of the fibril, while the dye dimers form stable complexes with the amyloid groove formed by the residues Q15 and E17 of the A-chain, and located on the wet interface of the fibril. The latter binding site is more easily accessible and is additionally stabilized by the electrostatic interactions between the positively charged dye and the E17 residue. This binding mode seems to be prevailing over that for the AK3-1 monomers. Based on the results obtained, AK3-1 may be recommended as a prospective amyloid marker complementary to the classical amyloid reporters Thioflavin T and Congo Red.

KEYWORDS: Trimethine cyanine dyes, amyloid marker, H-aggregates, insulin

\section{НОВИЙ ТРИМЕТИНОВИЙ ЦАНІНОВИЙ БАРВНИК ЯК ПОТЕНЦІЙНИЙ АМІЛОЇДНИЙ МАРКЕР У. Тарабара ${ }^{1}$, О. Рижова ${ }^{1}$, К. Вус ${ }^{1}$, А. Курутос ${ }^{2}$ В. Трусова ${ }^{1}$, Г. Горбенко ${ }^{1}$, Н. Гаджев², Т. Делігеоргієв ${ }^{2}$ ${ }^{1}$ Кафедра ядерної та медичної фізики, Харківський начіональний університет імені В.Н. Каразіна пл. Свободи 4, Харків, 61022, Україна \\ ${ }^{2}$ Факультет хімії і фармачії, Софійський університет, Софія, 1164, Болгарія}

За допомогою методу абсорбційної спектроскопії проведена оцінка можливості використання нового ціанінового барвника АК3-1 для детектування та характеризації патогенних білкових агрегатів, амілоїдних фібрил. Спектри поглинання АК3-1 в органічному розчиннику диметилсульфоксиді (ДМСО) характеризуються наявністю вібронної структури, причому відносна інтенсивність субсмуги 0-0 вище, ніж інтенсивність субсмуги 0-1. У водній фазі відбувався гіпсохромний зсув спектру поглинання АК3-1 відносно ДМСО, обумовлений Н-агрегацією барвника. При взаємодії АК3-1 з нативним та фібрилярним інсуліном спостерігалось зменшення інтенсивності мономерної спектральної смуги та зростання інтенсивності смуги Ндимерів. Для оцінки відносних внесків пономерної та агрегованої форм барвника , була проведена деконволюція спектрів поглинання зв'язаного з білком АК3-1 з використанням асиметричної лог-нормальної (LN) функції. Аналіз набору параметрів, отриманих в процесі підгонки, вказує на самоасоціацію АК3-1 в димери типу «голова до голови» викликану білком, причому величина цього ефекту була значно більш виражена в присутності фібрилярного білка. 3 використанням методу молекулярного докінгу показано, що мономери АК3-1 зв'язуються зі специфічно розміщеними боковими ланцюгами $\beta$-листа, що сформовані залишками лейцину L17 (В ланцюга інсуліну) та знаходяться на повністю недоступній для води поверхні - стеричній блискавці. В той же час, димери барвника формують стабільні комплекси 3 жолобками фібрил, що утворені амінокислотними залишками Q15 та Е17 ланцюга А та розташовані на доступній для розчинника поверхні. Сайт зв'язування Q15_E17 є більш доступним для барвника, а також додатково стабілізується електростатичною взаємодією між позитивно зарядженим барвником та залишком Е17. Останній механізм взаємодії уявляється переважним порівняно 3 механізмом зв'язування мономерів 3 фібрилами. Отримані результати дозволяють рекомендувати АК3-1 в якості перспективного амілоїдного маркера, поряд з класичними репортерськими молекулами Тіофлавіном Т та Конго червоним.

КЛЮЧОВІ СЛОВА: Триметинові ціанінові барвники, амілоїдний маркер, Н-агрегати, інсулін

НОВЫЙ ТРИМЕТИНОВЫЙ ЦИАНИНОВЫЙ КРАСИТЕЛЬ КАК ПОТЕНЦИАЛЬНЫЙ АМИЛОИДНЫЙ МАРКЕР

У. Тарабара ${ }^{1}$, О. Рыжова ${ }^{1}$, К. Вус ${ }^{1}$, А. Курутос ${ }^{2}$, В. Трусова ${ }^{1}$, Г. Горбенко ${ }^{1}$, Н. Гаджев ${ }^{2}$, Т. Делигеоргиев ${ }^{2}$

${ }^{1}$ Кафедра ядерной и медииинской физики, Харьковский национальный университет имени В.Н. Каразина пл. Свободьи 4, Харьков, 61022, Украина

${ }^{2}$ Факультет химии и фармации, Софийский университет, София, 1164, Болгария

С помощью метода абсорбционной спектроскопии проведена оценка возможности использования нового цианинового красителя АКЗ-1 для детектирования и характеризации патогенных белковых агрегатов, амилоидных фибрилл. Спектры поглощения АК3-1 в органическом растворителе диметилсульфоксиде (ДМСО) характеризуются наличием вибронной структуры, причем относительная интенсивность субполосы 0-0 выше, чем интенсивность субполосы 0-1. В водной фазе 
полоса поглощения красителя претерпевает гипсохромный сдвиг по отношению к ДМСО, обусловленный Н-агрегацией красителя. При взаимодействии АК3-1 с нативным и фибриллярным инсулином наблюдалось уменьшение мономерной спектральной полосы и рост полосы Н-димеров. Для оценки относительных вкладов мономерной и агрегированной форм красителя, была проведена деконволюция спектров поглощения связанного с белком АК3-1 с использованием асимметричной лог-нормальной (LN) функции. Анализ набора параметров, полученных в процессе подгонки, указывает на вызванную белком самоассоциацию АK3-1 в димеры типа «голова к голове», причем величина этого эффекта была гораздо более выражена в присутствии фибриллярной формы белка. С использованием метода молекулярного докинга показано, что мономеры АК3-1 связываются со специфически размещенными боковыми цепями $\beta$-листа, сформированными лейциновыми остатками L17 (принадлежащими цепи В), которые находятся в стерической молнии (поверхности фибриллы полностью недоступной для воды). В то же время, димеры красителя формируют стабильные комплексы с желобками фибрилл, сформированными аминокислотными остатками Q15 и Е17 цепи А, которые расположены на доступной растворителю поверхности. Сайт связывания Q15_Е17 является более доступным для красителя и дополнительно стабилизируется электростатическими взаимодействиями между положительно заряженным красителем и остатком Е17. Последний механизм взаимодействия представляется предпочтительным по сравнению с механизмом связывания мономеров с фибриллами. Полученные результаты позволяют рекомендовать АК3-1 в качестве перспективного амилоидного маркера, дополнительного к классическим репортерским молекулам Тиофлавину Т и Конго красному.

КЛЮЧЕВЫЕ СЛОВА: Триметиновые цианиновые красители, амилоидный маркер, Н-агрегаты, инсулин

Protein misfolding followed by the deposition of the specific highly ordered protein assemblies, amyloid fibrils, in various tissues and organs are involved in the molecular etiology of a wide variety of severe diseases, including neurodegenerative disorders, systemic amyloidosis, familial amyloid polyneuropathy, type 2 diabetes, etc [1]. Accumulating evidence lends support to the hypothesis that structural transformation of a polypeptide chain into partially folded conformation is a critical prerequisite for fibril formation. In vitro, fibrillization-favoring conditions are created by lowering $\mathrm{pH}$, elevating temperature, adding organic solvents or denaturants, etc., while in vivo, abnormal partial unfolding or folding may arise from mutations, oxidative or heat stress or destabilization of the protein structure upon its adsorption at interfaces such as cellular membranes [2,3]. Importantly, the morphology and physicochemical properties of amyloid fibrils are not encoded in the polypeptide sequence since the fibrillar states of different proteins are characterized by a similar cross- $\beta$ core structure with some variations in a final architecture of the mature fibrils [35]. Due to their unique physicochemical properties, biocompatibility and biodegradability, the fibrillar protein selfassemblies are regarded as attractive candidates for creating the nanostructured materials for different areas of medicine, science and technology [6-8]. Among a variety of powerful physical tools currently used for identification and characterization of amyloid fibrils an important place belongs to fluorescence and absorption spectroscopy techniques involving the amyloid-specific chromo- and fluorophores [9-12]. The classical amyloid markers possessing high affinity for the $\beta$-pleated structure are Thioflavin $\mathrm{T}$ and Congo Red [13-17]. Likewise, a marked specificity for amyloid fibrils was observed for other classes of dyes including naphthalenes, oligothiophenes, curcumin derivatives, cyanines, etc. [19-20]. Among these, cyanine dyes attract special attention due to their unique photophysical properties, such as: i) high extinction coefficients; ii) long-wavelength absorption and emission bands; iii) high fluorescence quantum yield, iv) noticeable absorbance and/or fluorescence changes upon association with $\beta$-sheet structure [21-23].

A series of mono-, tri-, penta-, and heptamethinecyanine dyes were reported to display a strong fluorescence increase upon binding to fibrillar beta-lactoglobulin [24], a-synuclein [25-27], insulin [28], lysozyme [22, 29], A $\beta$ fibrils [30]. Remarkably, the trimethine cyanine dyes have been used for real-time, non-radioactive $A \beta$ imaging in vivo [31]. Nevertheless, some of these compounds have the drawbacks among which are small Stokes shifts [32], poor water solubility [33], low photostability in aqueous solutions arising from the flexibility of polymethine chain [34-35], and high tendency to aggregate complicating the quantitative analysis of spectral data [36]. In view of this, there is a strong need for the synthesis, testing and versatile characterization of the novel cyanines dyes. The aim of the present study was two-fold: i) to characterize the ability of the newly synthesized near-infrared cyanine trimethine dye, AK3-1, to selectively recognize the amyloids fibrils, and ii) to perform comparative analysis of the spectral behavior of AK3-1 bound to native and fibrillar insulin.

\section{EXPERIMENTAL SECTION Materials}

Bovine insulin was from Sigma (Sigma, St. Louis, MO, USA). The trimethine cyanine dye AK3-1 (inset in Fig. 1A) was synthesized in the University of Sofia, Bulgaria, as described previously [40]. The stock solution of AK3-1 was prepared by dissolving the dye in DMSO, then diluted by $5 \mathrm{mM}$ sodium phosphate buffer (pH 7.4) and used for spectroscopic measurements. The concentration of AK3-1 was determined spectrophotometrically, using the extinction coefficient $\varepsilon_{628}=1.36 \times 10^{5} \mathrm{M}^{-1} \mathrm{~cm}^{-1}$.

\section{Preparation of amyloid fibrils}

Insulin, used here as a model protein, is a small hormone regulating the glucose homeostasis and lipid metabolism, that is capable of forming fibrils under denaturing conditions such as elevated temperatures, low $\mathrm{pH}$, the presence of organic solvents, agitation, etc. [38,39]. Insulin amyloid fibrils were obtained in vitro by the protein incubation in glycine buffer $(\mathrm{pH} 2)$ at $37{ }^{\circ} \mathrm{C}$ under continuous shaking for 6 days. Protein concentration in the stock solution was 
$10 \mathrm{mg} / \mathrm{ml}$. The working solutions of the native and fibrillar insulin were prepared in $5 \mathrm{mM}$ sodium phosphate buffer (pH 7.4). Hereafter, the native and fibrillar protein forms are referred to as InsN and InsF, respectively.

\section{Absorption measurements}

The absorption spectra of AK3-1 were recorded with the spectrophotometer Shimadzu UV-2600 (Japan) at $25^{\circ} \mathrm{C}$ using 10-mm path-length quartz cuvettes. Deconvolution of AK3-1 absorption spectra was performed with Origin 9.0 (OriginLab Corporation, Northampton, USA) using the log-normal asymmetric function (LN) [41]:

$$
A=A_{\max } \exp \left[-\frac{\ln 2}{\ln ^{2}(\rho)} \ln ^{2}\left(\frac{a-v}{a-v_{C}}\right)\right]
$$

where $A$ is the absorbance, $A_{\max }$ is the maximum of absorbance, $v$ is the wavenumber, $v_{C}$ is the position of the peak, $\rho$ is the asymmetry of the function defined as:

$$
\rho=\frac{v_{C}-v_{\min }}{v_{\max }-v_{C}}
$$

where $v_{\min }$ and $v_{\max }$ denote the wavenumber values at half-absorbance. The parameter $a$ designates the limiting wavenumber:

$$
a=v_{C}+\frac{\left(v_{\max }-v_{\text {min }}\right) \cdot \rho}{\rho^{2}-1}
$$

\section{Molecular docking study}

The molecular docking was performed to identify the possible sites for the AK3-1 binding to insulin molecule and to elucidate the nature of the interactions between the dye and either native or fibrillar protein. The coordinates for the native protein were taken from the bovine insulin hexameric form, PDB ID: 2ZP6, while the coordinates for amyloid fibrils were generated from http://people.mbi.ucla.edu/sawaya/jmol/fibrilmodels/ [42]. The model of fibrillar protein was built based on the crystal structure of the segment LVEALYL (human insulin B chain, the residues 11-17). The aggregated insulin was represented by the two protofilaments each containing 8 strands. The structure of AK3-1 was built and optimized in Avogadro. The top 10 most energetically favorable dye-protein structures were obtained using the PatchDock algorithm that is suitable for the protein-ligand and protein-protein complexes, and then refined by the FireDock, as described previously [29]. The docked complexes were viewed by the Visual Molecular Dynamics (VMD) software (version 1.9.3).

\section{RESULTS AND DISCUSSION}

As can be seen from Fig. 1A, AK3-1 is a cationic unsymmetric trimethine cyanine dye, the positive charge of which is associated with the left-hand nitrogen atom. In an organic solvent, DMSO, AK3-1 is characterized by a broad absorption spectrum within the range $450-700 \mathrm{~nm}$, with the maximum at $637 \mathrm{~nm}$ and a second sub-peak at $569 \mathrm{~nm}$. Increasing the solvent polarity upon the dye transfer from DMSO to the buffer solution resulted in a $\sim 15 \mathrm{~nm}$ shift of the absorption maximum position coupled with a spectrum broadening (Fig. 1A). Accordingly, in the aqueous phase the dye absorption spectrum was featured by two-peak structure with absorption maximum at $622 \mathrm{~nm}$, a sub-band at 556 $\mathrm{nm}$ and the small shoulder around $510 \mathrm{~nm}$.

Numerical studies indicate that the absorption spectra of cyanine dyes possess a vibronic structure with the relative intensities of 0-0 and 0-1 sub-bands being dependent on the dye structure [43, 44]. The main absorption band of AK3-1 centered at $\sim 622 \mathrm{~nm}$ in the buffer solution (637 nm in DMSO) corresponds to the 0-0 transition, whereas a second subband can be assigned to 0-1 transition. However, the AK3-1 aggregation seems to occur in the aqueous medium and the blue-shifted shoulder around $510 \mathrm{~nm}$ can be assigned, most probably, to the H-dimer of the dye. The hypsochromically shifted bands of $\mathrm{H}$-aggregates are generally explained in the terms of the exciton coupling theory proposed by Kasha. Briefly, for a face-to-face stacked H-dimer the two exciton states appeared due to the coupling of the transition moments of the two consistent dye molecules, with the transition to the higher energy state, the phenomenon manifesting itself in the blue shift of the absorption spectra [47].

Shown in Fig. 1B and Fig. 1C are the absorption spectra of AK3-1 measured at increasing concentrations of the native and fibrillar insulin, respectively. The addition of the native insulin to the dye in buffer solution resulted in a marked decrease in the absorbance of monomer band and vibrational sub-band coupled with the broadening of the absorption spectra and the increase of a shoulder at $510 \mathrm{~nm}$. In the presence of fibrillar insulin the following effects were observed: i) a hypochromism in the monomer absorbance augmenting with the InsF concentration; ii) the appearance of a second well-defined peak at $510 \mathrm{~nm}$. Although clear isosbestic points are not observed in the absorption spectra of AK3-1 in the presence of insulin, the apparent isosbestic points can be distinguished around $545 \mathrm{~nm}$ and 650 $\mathrm{nm}$ for InsN and at $452 \mathrm{~nm}$ and $650 \mathrm{~nm}$ for InsF. For the both protein forms, the shoulder and peak at $510 \mathrm{~nm}$ can be 
distinguished around $545 \mathrm{~nm}$ and $650 \mathrm{~nm}$ for InsN and at $452 \mathrm{~nm}$ and $650 \mathrm{~nm}$ for InsF. For the both protein forms, the shoulder and peak at $510 \mathrm{~nm}$ can be interpreted in terms of the insulin-induced AK3-1 self-association into the head-tohead dimers, with the magnitude of this effect being much more pronounced for the fibrillar protein aggregates. Remarkably, the tendency to organize into card-pack assemblies on the fibrillar matrix of $\beta$-amyloid peptide was previously observed for the cationic piacyanol dye [30]. The ability of rhodamine $6 \mathrm{G}$ to aggregate on the amyloid fibril template was found by Hanczyc et al. [48], who demonstrated that the structural differences between the lysozyme and insulin amyloid fibrils promote the formation of the J-type and H-type molecular arrangements of the dye, respectively. The enhanced aggregation of the cyanine dye 7514 in the presence of fibrillar insulin was reported also by Volkova et al. [28] who ascribed the band shifted to the long-wavelength region relative to the monomer band to the formation of the J-aggregates on the insulin fibrils.
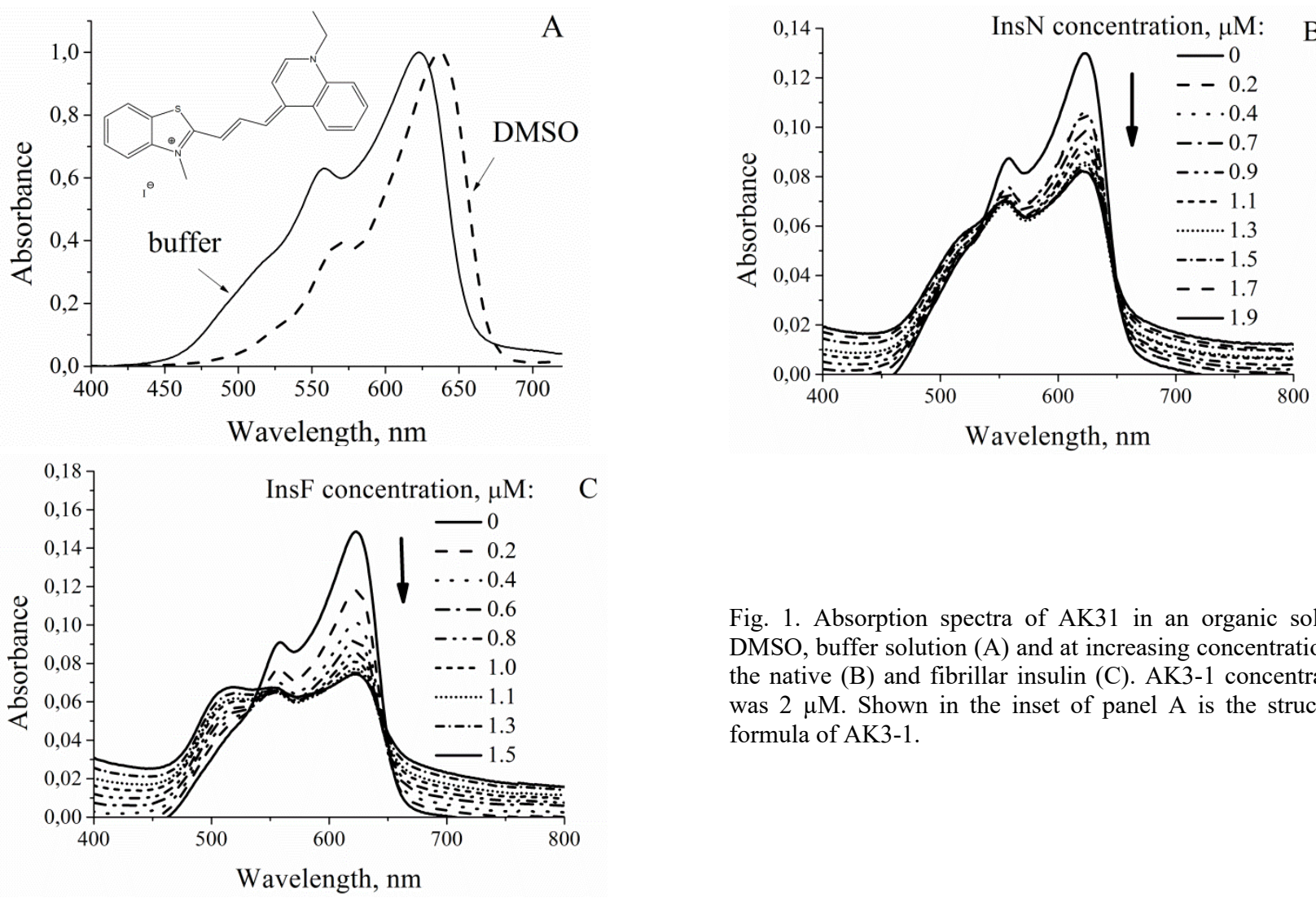

Fig. 1. Absorption spectra of AK31 in an organic solvent DMSO, buffer solution (A) and at increasing concentration of the native $(\mathrm{B})$ and fibrillar insulin $(\mathrm{C})$. AK3-1 concentration was $2 \mu \mathrm{M}$. Shown in the inset of panel $\mathrm{A}$ is the structural formula of AK3-1.

To analyze the spectral behavior of AK3-1 in more detail, we performed the decomposition of the dye absorption spectra using the log-normal asymmetric function (Eq. 1). Presented in Fig. 2 are the results of the deconvolution of AK3-1 spectra in the buffer solution and in the presence of the native and fibrillar insulin.

The choice of LN function was dictated mainly by a highly asymmetric nature of the AK3-1 absorption spectra. As was demonstrated in the recent study of Laurdan fluorescence spectra, in the case of asymmetry in the spectral shape, the decomposition procedure is more accurate when using the log-normal function [41]. The results of the AK3-1 spectra deconvolution with the asymmetric log-normal function are shown in Fig. 2 and Tables 1, 2. It appeared that the dye absorption spectra can be represented as a sum of two separate bands, with a short-wavelength and long-wavelength spectral components corresponding to the dimeric and monomeric dye species, respectively.

Spectral characteristics of AK3-1 absorption in the aqueous and protein phase (band I)

\begin{tabular}{|l|c|c|c|c|c|c|c|}
\hline System & $A_{\max }$ & $v_{c}, \mathrm{~cm}^{-1}$ & $v_{\min }, \mathrm{cm}^{-1}$ & $v_{\max }, \mathrm{cm}^{-1}$ & FWHM, $\mathrm{cm}^{-1}$ & $\rho, \mathrm{cm}^{-1}$ & $R^{2}$ \\
\hline Buffer & 59413.2 & 16007.5 & 15502.6 & 17150 & 1647.4 & 0.442 & 0.98 \\
\hline InsN & 31973 & 16007.5 & 15502 & 17150 & 1648 & 0.442 & 0.97 \\
\hline InsF & 23342.8 & 16007 & 15502 & 17150 & 1648 & 0.442 & 0.98 \\
\hline
\end{tabular}

The addition of the native and fibrillar insulin to AK3-1 in buffer was accompanied by the decrease in the amplitude of band I coupled with a concomitant increase of the band II. This effect was most pronounced in the case of fibrillar insulin showing $\sim 2.5$-fold decrease in the intensity of band I relative to the buffer solution, while for the native insulin $\sim 1.9$-fold reduction of the band I was observed. Taken into account that the band I and II correspond to the 
absorption of monomeric and dimeric dye forms, respectively, the decrease of the amplitude of band I along with the increase of $A_{\max }$ values for band II demonstrates one important feature: the native and fibrillar insulin may serve as a matrix for AK3-1 dimerization.

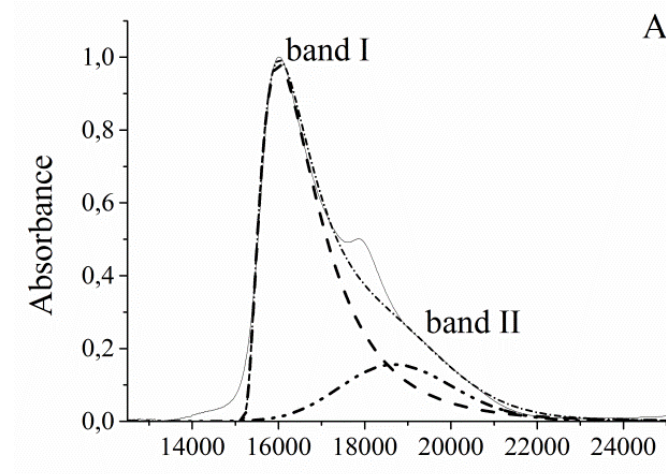

Wavenumber, $\mathrm{cm}^{-1}$

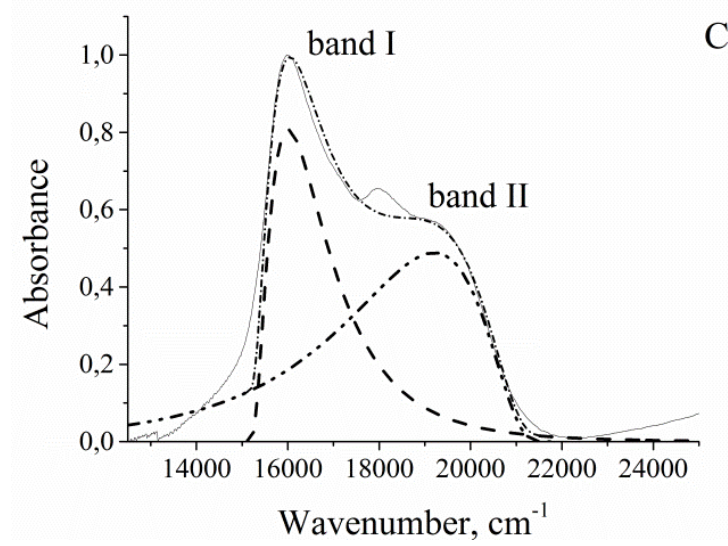

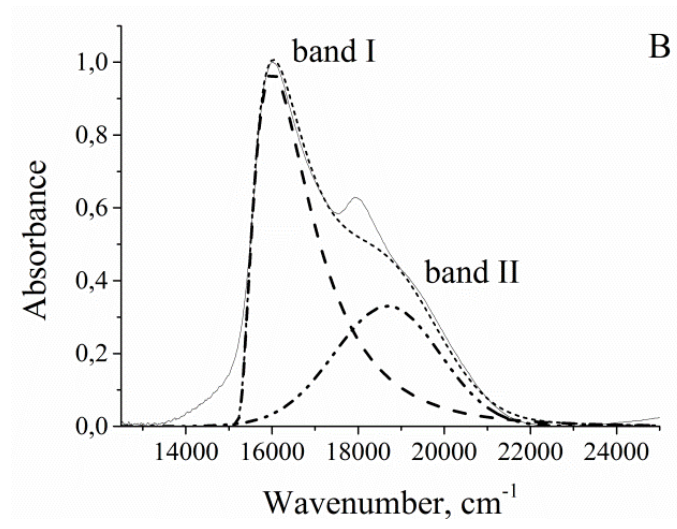

Fig. 2. Deconvolution of AK3-1 spectra in the buffer solution (A) and in the presence of native (B) and fibrillar insulin (C). Protein concentration was $1.5 \mu \mathrm{M}$

Spectral characteristics of AK3-1 absorption in the aqueous and protein phase (band II)

\begin{tabular}{|l|c|c|c|c|c|c|c|}
\hline Medium & $A_{\max }$ & $v_{c}, \mathrm{~cm}^{-1}$ & $v_{\min }, \mathrm{cm}^{-1}$ & $v_{\max }, \mathrm{cm}^{-1}$ & FWHM, $\mathrm{cm}^{-1}$ & $\rho, \mathrm{cm}^{-1}$ & $R^{2}$ \\
\hline Buffer & 9457.6 & 18685.9 & 17223.2 & 20298.4 & 3075.2 & 0.907 & 0.98 \\
\hline InsN & 10853.9 & 18685.9 & 17223 & 20111.2 & 2888.2 & 1.026 & 0.97 \\
\hline InsF & 14142.2 & 19200 & 16669.2 & 20481.9 & 3812.7 & 1.974 & 0.98 \\
\hline
\end{tabular}

While comparing the full width at half-maximum (FWHM), it can be seen that the association of AK3-1 with InsN and InsF is followed by the FWHM change only for the band II, with the signs of this effect being opposite for the native and fibrillar protein forms. Specifically, the insulin fibrils produced a significant increase in FWHM, whereas in the presence of the native insulin this parameter displayed a slight decrease. Moreover, the dye transfer from the aqueous to protein phase did not affect the position of the peaks I and II, with the exception of $v_{c}$ for the band II in the insulin fibrils where a small short-wavelength shift was observed. Since the $v_{c}$ value is generally related to the environmental polarity [41], we cannot rule out the possibility that AK3-1 associated with InsF experiences a microenvironment with decreased polarity. However, when considered together with the growth of FWHM value, the increase in $v_{c}$ is most likely to originate from the higher aggregation ability of AK3-1 in the presence of fibrillar insulin. It can be assumed that not only dimers but also higher-order dye aggregates are formed on the fibril matrix. The validity of this assumption is corroborated by the finding that the asymmetry parameter is significantly greater for the band II in the case of fibrillar insulin.

The self-assembly of dye molecules, especially cyanines, into supramolecular aggregates has been widely investigated indicating that the aggregation pathways and the types of forming aggregates depend on a variety of factors, such as dye structure, temperature, the environmental polarity, the presence of salt, etc. [49]. The nucleic acids, proteins, polymers, lipid assemblies and surfactants have been examined in the context of designing and controlling the aggregation pattern of various dyes [49,50]. The physical background of dye aggregation lies in the dipole-dipole coupling between the transition dipole moments of neighboring molecules which leads to the Frenkel exciton appearance. The inclusion of the exciton-vibrational coupling in the model describing the absorption and emission spectra of the linear H- and J-aggregates with the nearest-neighbor-only coupling $\left(J_{o}\right)$ as a function of coupling 
strength was performed by Spano [51]. Assuming a monomer spectrum with a vibronic fine-structure being governed by the Franck-Condon progression with the 0 -n intensity scaling as $S^{n} \exp (-S) / n$ ! ( $S$ is the Huang-Rhys factor), he associated the spectral differences of aggregation patterns with the aggregates in the weak and strong coupling regimes. The absorption spectrum of the former is characterized by three peak structure, while in the strong excitonic coupling regime, the oscillator strength is mainly concentrated in a single band. Taking into account the complex nature of the dye-protein interactions and the fact that the dye-protein complexes and the dye aggregates are stabilized by the same types of intermolecular forces (van der Waals, H-bonding, electrostatic and hydrophobic interactions), it is difficult to answer whether the aggregates of the protein-bound AK3-1 exist in the weak or strong coupling regimes. However, allowing for the very weak emission of AK3-1 in the protein phase (data not shown) we are prone to consider the strong coupling regime as being more probable.

To explain the aggregation behavior of cationic AK3-1 in the protein phase, it should be noted that initially, in the aqueous phase only a small portion of dimers are present because of very low dye concentration limiting the formation of the dye-dye contacts. The dye transfer from the polar buffer solution to the protein phase stimulates the formation of AK3-1 aggregates. The fact that the highest aggregation potential of AK3-1 was observed in the presence of InsF, suggests that the fibrillar protein has either more binding sites for cyanine aggregates than InsN, or a more favorable environment for the dye self-assembly. Presumably, the hydrophobic, electrostatic, and van der Waals interactions between the dye and the native or fibrillar protein promote the formation of the dye H-aggregates. The presence of the negatively charged insulin cavities favors the electrostatic interactions with the positively charged AK3-1. However, taking into account that InsF has more exposed hydrophobic residues compared to InsN, the contribution of hydrophobic interactions to the formation of the complexes "H-dimer-protein" is likely to be predominant. Furthermore, typical fibril binding sites for the small organic molecules are represented by the long surface grooves running parallel to the fibril axis, which may induce the end-by-end stacking of the fibril-bound AK3-1 molecules, followed by the dye dimerization [52]. Therefore, to identify AK31-insulin binding sites, as well as the nature of the interactions involved in the dye-protein complexation in the native protein and amyloid fibrils, a series of simple molecular docking studies were performed.
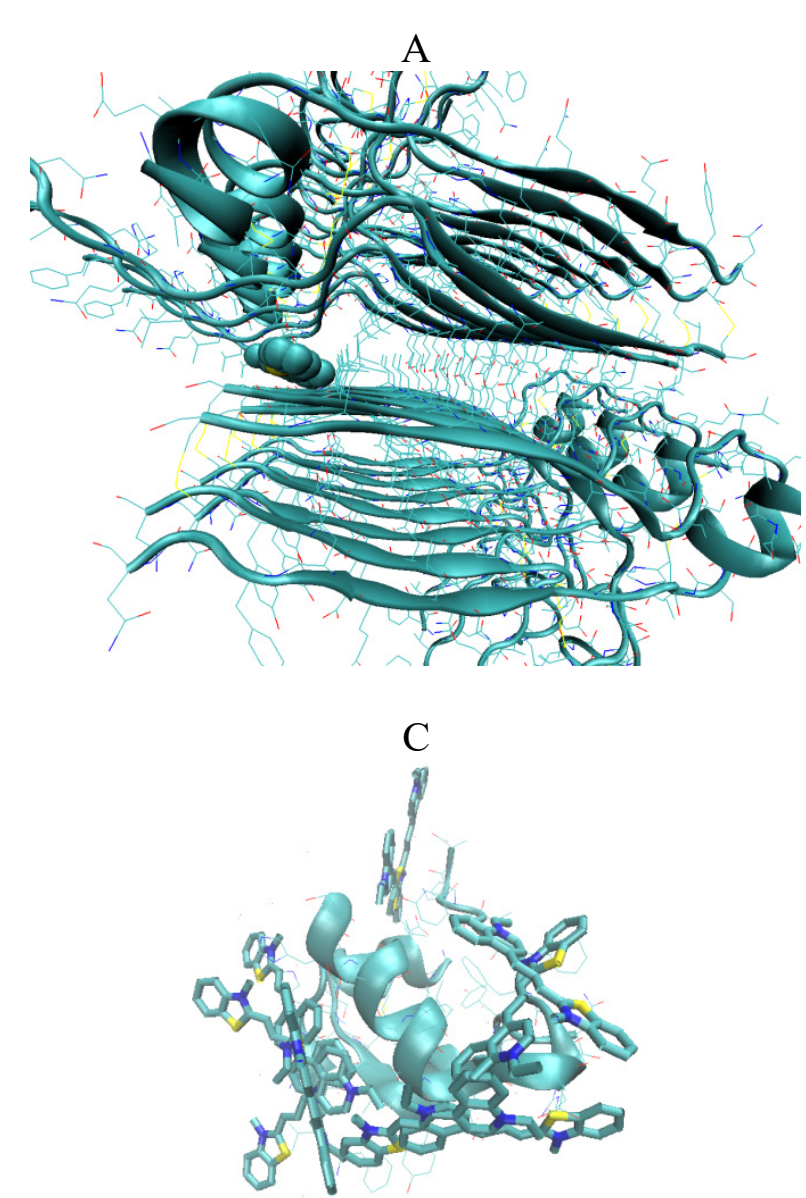

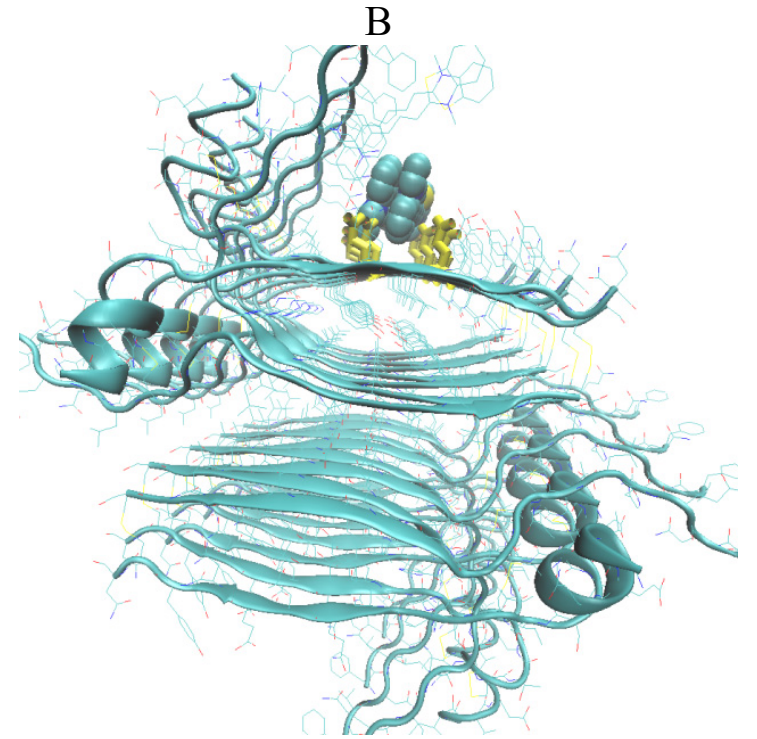

$\mathrm{D}$

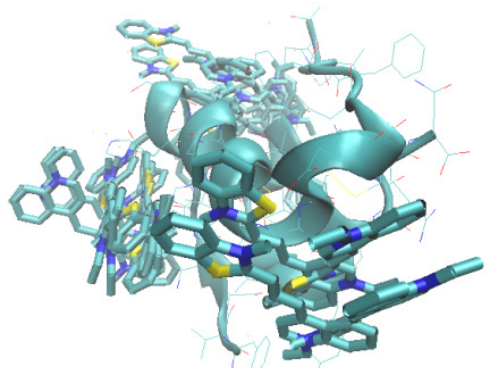

Fig. 3. AK3-1 monomer (A) and dimer (B) complexes with fibrillar insulin and the most energetically favorable AK3-1 monomer (C) and dimer (D) complexes with the native insulin, obtained using the molecular docking. Ligand and protein are represented via VDW/ Bonds and New Cartoon/ Lines/ Bonds methods, respectively. The residues Q15 and E17 of the A-chain are colored in yellow. 
As seen in Fig. 3A, the AK3-1 monomer tends to associate with the cross-strand ladder (a specific arrangement of side chains in the $\beta$-sheet) formed by B17 leucine residues (of the insulin B-chain), located on the dry steric zipper interface of the fibril. These results are in accordance with those reported for Thioflavin $\mathrm{T}$, which possesses a high affinity for the leucine and tyrosine ladders of the model peptides [53,54]. In turn, the dye dimers form stable complexes with the amyloid groove formed by the residues Q15 and E17 of the A-chain, and located on the wet interface of the fibril. The latter binding site is more easily accessible and is additionally stabilized by the electrostatic interactions between the positively charged dye and E17 residue. Furthermore, it is AK3-1 dimer that has sufficient surface area to form the van der Waals and hydrophobic contacts with both Q15 and E17 residues, and thus, to fit the groove width. Interestingly, the cyanine amyloid inhibitor N44 was found to bind to the tau prefibrillar aggregates in the dimeric form [55]. However, the dye dimers also proved to associate with the coil structure of insulin (data not shown), suggesting that additional factors, viz. end-by-end stacking of the fibril-bound dimers, are needed to make the groove binding mechanism predominant.

Fig. 3C shows that AK3-1 monomer presumably associates with the insulin B-chain residues 17-22 (3-10-helix includes the residues B20-B22), as well as with the B-chain residues 1-4, via the hydrophobic and van der Waals interactions. In turn, AK3-1 dimer was also associated with the A-chain of the protein. However, the environment of the AK3-1 dimer bound to the native insulin is more polar and has lower surface area to form the dye-protein van der Waals contacts, compared to the Q15_E17 groove. Therefore, the AK3-1 binding to the native insulin may be less specific than to the amyloid fibrils. Indeed, similar to the typical amyloid markers, AK3-1 showed a higher fluorescence response to the fibrils compared to the native insulin (data not shown). Thus, AK3-1 seems to be entrapped into the amyloid assemblies followed by the dye dimerization, so that the dye dimers bind to the Q15_E17 groove with greater affinity than that for the native insulin, underlying the spectral effects observed for the absorption of the H-dimeric band.

\section{CONCLUSIONS}

- The analysis of the absorption spectra of the novel cyanine dye AK3-1 in the presence of native and fibrillar insulin points to the protein-induced AK3-1 self-association into the head-to-head dimers, with the magnitude of this effect being much more pronounced for the fibrillar protein aggregates. The aggregates of AK3-1 emerging on the protein matrix are presumably in a strong coupling regime.

- The molecular docking studies showed that the AK3-1 dimers are bound to the groove formed by the Q15_E17 residues of the insulin A-chain via hydrophobic, van der Waals and electrostatic interactions. This binding mode seems to be prevailing, while the binding site is more accessible and stable than that for the AK3-1 monomers, i.e. the cross-strand ladder formed by $\mathrm{L} 17$ residues of the B-chain.

- The revealed spectral behavior of the cyanine dye in the presence of monomeric and fibrillar forms of insulin, points to the possibility of using AK3-1 for the identification and structural characterization of amyloid fibrils.

\section{ACKNOWLEDGEMENTS}

This work was supported by the Ministry of Education and Science of Ukraine (the Young Scientist project № 0117U004966 "Nano- and microsized liophylic and liophylized self-associated systems: application in modern technologies and biomedicine") and by the President's of Ukraine grant No 0118 U002284 from the State Fund for Fundamental Research of Ukraine "Development of novel anti-amyloid strategies by high-throughput screening of inhibitors of pathological protein aggregation".

\section{ORCID IDs}

U. Tarabara (D) https://orcid.org/0000-0002-7677-0779, O. Ryzhova (D) http://orcid.org/0000-0001-9554-0090, K. Vus (1D http://orcid.org/0000-0003-4738-4016, A. Kurutos (iD https://orcid.org/0000-0002-6847-198X

V. Trusova (i) http://orcid.org/0000-0002-7087-071X, G. Gorbenko (iDttp://orcid.org/0000-0002-0954-5053

\section{REFERENCES}

[1]. V.N. Uversky and A.L. Fink, Biochim. Biophys. Acta. 1698, 131-153 (2004).

[2]. J. Adamcik and R. Mezzenga, Macromolecules. 45, 1137-1150 (2012).

[3]. C.M. Dobson, Cold Spring Harb. Perspect. Bio. 9, 1-14 (2017).

[4]. J.C. Rochet and P.T.Jr. Lansbury, Curr. Opin. Struct. Biol. 10, 60-68 (2000).

[5]. R. Nelson and D. Eisenberg, Adv. Protein Chem. 73, 235-282 (2006).

[6]. T.P.J. Knowles, T.W. Oppenheim, A.K. Buell, D.Y. Chirgadze and M.E. Welland, Nature Nanotechnology. 5, $204-207$ (2010).

[7]. U. Shimanovich, T.C.T. Michaels, E. De Genst, D. Matak-Vinkovic, C.M. Dobson and T.P.J. Knowles, Biomacromolecules. 18, 3052-3059 (2017).

[8]. V. Kovalska, S. Chernii, M. Losytskyy, I. Tretyakova, Y. Yan Dovbii, A. Gorski, V. Chernii, R. Czerwieniec and S. Yarmoluk, New J. Chem. 42, 13308-13318 (2018).

[9]. F. Chiti and C.M. Dobson, Annu. Rev. Biochem. 75, 333-366 (2006).

[10]. M.R. Nilsson, Methods. 34, 151-160 (2004).

[11]. O.S. Makin, E. Atkins, P. Sikorski, J. Johansson and L.C. Serpell, Proc. Natl. Acad. Sci. U.S.A. 102, 315-320 (2005). 
[12]. A.K. Buell, E.K. Esbjorner, P.J. Riss, D.A. White, F.I. Aigbirhio, G. Toth, M.E. Welland, C.M. Dobson and T.P.J. Knowles, Phys. Chem. Chem. Phys. 130, 20044-20052 (2011).

[13]. H. LeVine 3rd, Protein Sci. 2, 404-410 (1993).

[14]. W.E. Klunk, J.W. Pettegrew and D.J. Abraham, J. Histochem. Cytochem. 37, 1273-1281 (1989).

[15]. H. Naiki, K. Higuchi, M. Hosokawa and T. Takeda, Anal. Biochem. 177, 244-249 (1989).

[16]. K. Murakami, K. Irie, A. Morimoto, H. Ohigashi, M. Shindo, M. Nagao, T. Shimizu and T. Shirasawa, J. Biol. Chem. 278, 46179-46187 (2003).

[17]. R. Khurana, V.N. Uversky, L. Nielsen and A.L. Fink, J. Biol. Chem. 276, 22715-22721 (2001).

[18]. M.S. Celej, E.A. Jares-Erijman and T.M. Jovin, Biophys. J. 94, 4867-4879 (2008).

[19]. A. Åslund, C.J. Sigurdson, T. Klingstedt, S. Grathwohl, T. Bolmont, D.L. Dickstein, E. Glimsdal, S. Prokop, M. Lindgren, P. Konradsson, D.M. Holtzman, P.R. Hof, F.L. Heppner, S. Gandy, M. Jucker, A. Aguzzi, P. Hammarström and K.P.R. Nilsson, ACS Chem.Biol. 4, 673-684 (2009).

[20]. J. Sutharsan, M. Dakanali, C.C. Capule, M.A. Haidekker, J. Yang and E.A. Theodorakis, ChemMedChem. 5, 56-60 (2010).

[21]. G. Patonay, J.S. Kim, R. Kodagahally and L. Strekowski, Appl. Spectrosc. 59, 682-690 (2005).

[22]. M.V. Kuperman, S.V. Chernii and M.Y. Losytskyy, Anal. Biochem. 484, 9-17 (2015).

[23]. V.B. Kovalska, M.Y. Losytskyy, O.I. Tolmachev, Y.L. Slominskii, G.M. Segers-Nolten, V. Subramaniam and S.M. Yarmoluk, J. Fluoresc. 22, 1441-1448 (2012).

[24]. K.D. Volkova, V.B. Kovalska, A.O. Balanda, R.J. Vermeij, V. Subramaniam, Y.L. Slominskii and S.M. Yarmoluk, J. Biochem. Biophys. Meth. 70, 727-733 (2007).

[25]. K.D. Volkova, V.B. Kovalska, A.O. Balanda, M.Y. Losytskyy, A.G. Golub, R.J. Vermeij, V. Subramaniam, O.I. Tolmachev and S.M. Yarmoluk, Bioorg. Med. Chem. 16, 1452-1459 (2008).

[26]. K.D. Volkova, V.B. Kovalska, G.M. Segers-Nolten, G. Veldhuis, V. Subramaniam and S.M. Yarmoluk, Biotech. \& Histochem. 84, 55-61 (2009).

[27]. K.D. Volkova, V.B. Kovalska, M.Y. Losytskyy, G. Veldhuis, G.M. Segers-Nolten, O.I. Tolmachev, V. Subramaniam and S.M. Yarmoluk, J. Fluoresc. 20, 1267-1274 (2010).

[28]. K.D. Volkova, V.B. Kovalska, M.Y. Losytskyy, K.O. Fal, N.O. Derevyanko, Y.L. Slominskii, O.I. Tolmachov and S.M. Yarmoluk, J. Fluoresc. 21, 775-784 (2011).

[29]. K. Vus, U. Tarabara, A. Kurutos, O. Ryzhova, G. Gorbenko, V. Trusova, N. Gadjev and T. Deligeorgiev, Mol. BioSyst. 13, 970-980 (2017).

[30]. R. Sabate and J. Estelrich, J. Biopolymers. 72, 455-463 (2003).

[31]. J. Gu, U.R. Anumala, R.H. Haußen, J. Holzer, V. Goetschy-Meyer, G. Mall, I. Hilger, C. Czech and B. Schmidt, ChemMedChem. 8, $891-897$ (2013).

[32]. Z. Zhang and S. Achilefu, Org. Lett. 6, 2067-2070 (2004).

[33]. J. Pauli, T. Vag, R. Haag, M. Spieles, M. Wenzel, W.A. Kaiser, U. Resch-Genger and I. Hilger, Eur. J. Med. Chem. 44, 34963503 (2009).

[34]. C.D. Geddes, H. Cao and J.R. Lakowicz, Spectrochim. Acta, Part A. 59, 2611-2617 (2003).

[35]. A. Sanchez-Galvez, P. Hunt, M.A. Robb, M. Olivucci, T. Vreven and H.B. Schlegel, J. Am. Chem. Soc. 122, 2911-2924 (2000).

[36]. R.F. Khairutdinov and N. Serpone, J. Phys. Chem. B. 101, 2602-2610 (1997).

[37]. J.S. Kim, R. Kodagahally, L. Strekowski and G. Patonay, Talanta. 67, 947-954 (2005).

[38]. D.F. Waugh, J. Am. Chem. Soc. 68, 247-250 (1946).

[39]. D.F. Waugh, D.F. Wilhelmson, S.L. Commerford and M.L. Sackler, J. Am. Chem. Soc. 75, 2592-2600 (1953).

[40]. A. Kurutos, I. Crnolatac, I. Orehovec, N. Gadjev, I. Piantanida and T. Deligeorgiev, J Luminescence. 174, 70-76 (2016).

[41]. M. Bacalum, B. Zorila and M. Radu, Anal. Biochem. 440, 123-129 (2013).

[42]. M.I. Ivanova, S.A. Sievers, M.R. Sawaya, J.S. Wall and D. Eisenberg, Proc Natl Acad Sci U S A . 106, 18990-19995 (2009).

[43]. H. Mustroph, K. Reiner and B.Senns, Color. Technol. 133, 469-475 (2017).

[44]. H. Mustroph, K. Reiner, J. Mistol, S. Ernst, D. Keil and L. Henning, Chem. Phys. Chem. 10, 835-840 (2009).

[45]. A.Caroff, E. Litzinger, R. Connor, I. Fishman and B. Armitage, Langmuir. 18, 6330-6337 (2002).

[46]. S. Kirstein and S. Daehne, Int. J. Photoen. 2006, 1-21 (2006).

[47]. M. Kasha, H.R. Rawls and M. Ashraf El-Bayoumi, Pure. Appl. Chem. 11, 371-392 (1965).

[48]. P. Hanczyc, L. Sznitko, C. Zhong and A. Heeger, ASC Photonics. 2(12), 1755-1762 (2015).

[49]. A. Mishra, R. Behera, P. Behera, B. Mishra and G. Behera, Chem. Rev. 100, 1973-2012 (2000).

[50]. S. Mooi, S.N. Keller and B. Heyne, Langmuir. 30, 9654-9662 (2014).

[51]. S. Spano, Accounts of Chemical Research. 43(3), 429-439 (2010).

[52]. M. Groenning, M. Norrman, J. Flink, M. Weert, J. Bukrinsky, G. Schluckebier and S. Frokjaer, J. Struct. Biol. 159(3), 483-497 (2007).

[53]. M. Biancalana and S. Koide, Biochim. Biophys. Acta. 1804(7), 1405-1412 (2010).

[54]. M. Biancalana, K. Makabe, A. Koide and S. Koide, J. Mol. Biol. 385(4), 1052-1063 (2009).

[55]. M. Necula, C. Chirita and J. Kuret, Biochemistry. 44(30), 10227-10237 (2005). 